\title{
The Role of Intellectual Capital, Organizational Learning and Digital Transformation on the Performance of $\mathrm{SME}_{\mathrm{s}}$ in Denpasar,Bali-Indonesia
}

\author{
Nengah Ganawati \#1, Dewi Soraya \#2, I Made Yogiarta \#3 \\ ${ }^{\#}$ Faculty of Economics and Business, Warmadewa University, Denpasar, Bali-Indonesia
}

\begin{abstract}
This research is motivated by the idea that intellectual capital, organizational learning, and digital transformation are needed by medium-sized businesses to improve performance to maintain business sustainability during the covid-19 pandemic. The main purpose of this study is to determine the direct influence of intellectual capital and the indirect effect of organizational learning and the effect of digital transformation as a moderating variable on business performance. The sample of this study used 174 medium-sized business managers in Denpasar City, Bali-Indonesia. The results of the study found that digital transformation was able to strengthen the relationship between the influence of intellectual capital and organizational learning on the performance of medium-sized enterprises.
\end{abstract}

Keywords - Intellectual Capital, Organizational Learning, Digital Transformation, Medium Enterprise Performance.

\section{INTRODUCTION}

Small Medium Enterprises $\left[\mathrm{SME}_{\mathrm{s}}\right.$ ) have an important role in increasing the economic progress of a country and society by providing many jobs for the community and can increase the income of the area where the SMEs are located, especially in Bali. [1]. The Covid-19 pandemic has had a tremendous impact on business continuity in Indonesia. The economic crisis experienced by SMEs has also become a major threat to the national economy, considering that SMEs are the driving force of the domestic economy and the largest absorber of labor in the last decades. As the results of a survey by the Indonesian Institute of Sciences [LIPI] stated that during the Covid-19 pandemic, $94.69 \%$ of businesses experienced a decline in sales. Based on business scale, sales decreased by more than $75 \%$ experienced by $49.01 \%$ ultra-micro businesses, $43.3 \%$ micro-businesses, $40 \%$ small businesses, and $45.83 \%$ medium businesses. Based on the length of business, sales decreased by more than $75 \%$ experienced by $23.27 \%$ of businesses aged $0-5$ years, $10.9 \%$ of businesses aged $6-10$ years, and $8.84 \%$ of businesses that have been running for more than 10 years. Based on the sales method,[2].

Based on this fact, SME actors must change their business strategy into a science-based business strategy to have a highly competitive advantage and can develop over time as science and technology develops. In general, SME actors still have a tendency to use conventional based in running their business, so the products produced still contain undeveloped technology. Based on studies[3] and [4] states that if the SME actors focus on optimal management of intellectual capital, then MSME actors in Indonesia will be able to compete using the competitive advantages obtained through creative innovations generated by the capital in their study of intellectual property owned by SME managers.

Intellectual capital is an intangible asset/organizational capital that is a collection of people, change processes, and consumers that provide competitive value for the company. [5]. Intellectual capital in the MSME sector is the main weapon in efforts to improve organizational performance. If the intellectual capital in the organization is low, it will be very difficult to compete with similar businesses or even with other large companies. This argument is consistent with the findings [6], [7], and [8]. On the other hand, several other researchers have found that high intellectual capital does not always have an impact on organizational improvement. 
DOI: $\underline{10.51386 / 25815946 / i j s m s-v 4 i 3 p 122}$

Several other empirical shreds of evidence have found evidence that intellectual capital has no effect or even decreases organizational performance, as the findings of [9] and [10] [11]which provides evidence that there is a negative and significant relationship between intellectual capital and organizational performance. Next[12] in his study in the Iranian industry stated that in addition to intellectual capital has a direct effect on organizational performance, intellectual capital can affect indirectly organizational learning factors to also improve organizational performance.

This means that the high intellectual capital owned by members of the organization is not able to guarantee an effect on improving organizational performance if it is not mediated or encouraged by the right organizational learning process. The role of organizational learning is very important for institutions such as medium-sized businesses to improve their capabilities and continuously transform their organizations towards better knowledge management [Senge,1994]. The application of organizational learning to adapt to the conditions of higher education development for the interests of stakeholders including customers, government, and various other stakeholders. Learning outcomes carried out by the organization in a strict manner can encourage an organization to improve organizational performance and productivity.[13] as well as [14]which shows the influence of organizational learning on organizational performance. On the other hand, several other researchers have found that high organizational learning does not always have an impact on organizational improvement. Several other empirical shreds of evidence found that organizational learning had no effect or even decreased organizational performance, as the findings of[15] and [16].

Inconsistent research results are still found, so this study tries to review the variables that affect the performance of MSMEs, namely intellectual capital and organizational learning. Based on the view of contingency theory, that the design and use of the management control system design depend on the characteristics of the organization and the environmental conditions in which the system will be implemented.[17]. In connection with this argument, it can be said that intellectual capital and organizational learning factors in influencing organizational performance are determined or dependent on environmental conditions in implementing digital transformation in every company's operational activities.

Digital transformation is a radical and comprehensive shift in the use of technology to improve company performance. The function of human capital and the optimization of organizational learning processes can be carried out optimally if there is support, which is a radical and comprehensive shift in the use of technology with contingent objectives to improve company performance. The application of digital transformation is an organizational institution that influences the thinking patterns, behaviour patterns, and behaviour patterns of organizational members in producing products, serving consumers, and achieving organizational goals.

High intellectual capital when strengthened by the right digital transformation can boost organizational performance and if the ongoing organizational learning process is strengthened by high digital transformation, the learning process runs more effectively which in turn has an impact on improving organizational performance. This argument has been successfully proven empirically that SOE performance can be upgraded with digital transformation through competitive advantage [18]. Other findings also support that when a businessman carries out information technology-based transformations, he can automatically Upgrade SME competitiveness [19] and employee performance [20]

Based on the results of previous research, it has been found that research gaps on intellectual capital affect organizational performance through organizational learning which shows different research findings between one researcher and another, so further research is needed and is expected to clarify how the influence of intellectual capital on organizational performance through organizational learning. This research was developed by modifying the findings[12] by adding the digital transformation variable as a moderating variable, in the hope that it can strengthen the influence of intellectual capital and organizational learning on organizational performance, which in previous studies did not exist or were rarely used so that this became a renewable MSME performance model based on the application of digital technology to produce a comprehensive model to improve the performance of SMEs. 
DOI: $\underline{10.51386 / 25815946 / \mathrm{ijsms}-\mathrm{v} 4 \mathrm{i} 3 \mathrm{p} 122}$

Volume: 4 Issue: 3

May to June 2021

www.ijsmsjournal.org

\section{LITERATURE REVIEW AND HYPOTHESIS DEVELOPMENT}

\section{A. Resource-Based View Theory}

Resource-Based View [RBV] theory was developed by [21]. This theory explains that resource ownership is a critical success factor for competitive advantage in improving organizational performance. MSMEs in carrying out their operational activities to serve stakeholders are strongly influenced by the resources they have. Therefore, MSME resources need to be developed so that the company becomes superior and competitive, which in turn can improve MSME performance in producing useful decisions so that the company can be trusted by clients and stakeholders. The MSME resource developed in this study is intellectual capital as an intangible asset of the company.

\section{B. Contingency Theory}

Contingency theory states that there is no universally applicable management and control accounting system. The appropriate accounting and control techniques to use depend on the circumstances or contingent factors affecting a company. Several key contextual factors can affect the accuracy of the selection of accounting techniques, namely the external environment, technology [both traditional and contemporary], organizational structure, size, strategy, and national culture.[17]. Important ideas from Contingency Theory include 1] There is no universal or best way to manage 2] A variety of external and internal factors must be considered and the focus should be on the actions that are best suited to a given situation 3] Effective organizations not only have a 'fit' ' right with the environment but also between the subsystems 4] Organizational needs will be more satisfied when it is designed and the management style is appropriate both for the task being performed and the nature of the workgroup. 5] Each manager's situation should be looked at separately 6] Managers need to be developed in the skills that are most useful in identifying important situational factors[22]

\section{Intellectual Capital, Organizational Learning, and Performance of Medium ENTERPRISES}

Intellectual capital is defined as intellectual material owned and formulated and leveraged to create wealth in the form of higher value assets [Stewart, 1997 and Bontis, 1998]. Well-developed intellectual capital can increase the effectiveness of organizational learning processes and have an impact on improving organizational performance.[15] Stating that the increase in intellectual capital and productive capacity for self-development is carried out continuously through an organizational learning process to increase job satisfaction. [23]Conducted research using three elements of intellectual capital, namely human capital, customer capital, and structural capital, and their relationship to performance in the Industrial sector in Canada and Malaysia. This study concludes that there is a relationship between intellectual capital and industrial performance, although there are differences where customer capital, and structural capital, companies are related to Canadian industrial performance, while in Malaysia only structural capital elements are related to industrial performance.[6]Surveying 253 Croatian MSMEs, it was successfully proven that the key dimensions of intellectual capital play an important role in the company's success and are closely interrelated. That higher MSME performance is positively associated with higher levels of intellectual capital and innovation culture.[12] Organizational innovation and learning is the best important basis for improving performance and gaining a competitive advantage. Therefore, this study wants to investigate and model the relationship between human capital and new product development performance efficiency concerning the mediating role of organizational learning capacity in the automotive industry in Iran. In this study, the results were obtained with structural equations and path models. The results show that human capital can improve new product development performance with organizational learning abilities. Based on the description of the research results between intellectual capital on organizational learning and organizational performance, the formulation of this research hypothesis can be arranged as follows:

H1. Better intellectual capital will be able to improve the performance of SMEs.

H2. Better intellectual capital will be able to improve organizational learning.

H4. The better intellectual capital will be able to improve organizational performance mediated by organizational learning.

\section{Organizational Learning on the Performance of Medium Enterprises}

[24] Explain that organizational learning is a process of detecting and correcting errors, to improve organizational performance. Organizational learning occurs when organizational members respond and change 
DOI: $\underline{10.51386 / 25815946 / \mathrm{ijsms}-\mathrm{v} 4 \mathrm{i} 3 \mathrm{p} 122}$

Volume: 4 Issue: 3

May to June 2021

www.ijssmsjournal.org

their environment both internally and externally by detecting and evaluating errors in the theory used and storing them for the formation of personal images and the common interests of the organization. Next [25] in his research found that managerial commitment, system perspective, openness and experimentation as well as knowledge transfer and integration have a significant relationship to organizational learning. Managerial commitment is an effective managerial activity starting from planning, implementation, administration, and reporting. The higher the level of managerial commitment, the higher the business performance. System perspective is a person's point of view related to a particular thing or problem. The better the system perspective of a company, the better the business performance. The higher the level of openness and experimentation, the better the performance of the business. The purpose of knowledge transfer and integration is to utilize employees so that they are willing to work hard and participate actively in supporting the achievement of business goals. The higher the level of knowledge transfer and integration, the higher the business performance. The finding of the positive influence of organizational learning on business performance is supported by [13] and [14]In the results of the study, it was proven that there was a significant, strong, and positive impact of organizational learning on performance from an employee perspective. Companies that invest effort into a systematic approach to organizational profit learn in terms of increased levels of employee confidence in leadership, increased organizational work efficiency, a more committed workforce, decreased cost of work per employee, increased employee satisfaction, and increased employee flexibility. [26] stated that hard skills and soft skills have a positive and significant effect on teacher innovation abilities, either directly or indirectly through organizational learning mediation, then teacher innovation abilities have a positive and significant impact on performance.Based on the description of the research results between organizational learning and organizational performance, the hypothesis of this research can be formulated as follows:

$\mathrm{H} 3$. Better organizational learning will be able to improve organizational performance.

\section{E. Digital Transformation}

In general, digital transformation is a radical and comprehensive shift in the use of technology to improve company performance. The definition of digital transformation states that digital transformation is a change caused or influenced by the use of digital technology in every aspect of human life. When businesses are forced to change due to the Covid-19 pandemic, promotions can be done through online applications. Digital transformation can work if there is a commitment from MSME managers, such as offering products through social media, giving discounts, and so on. Four things can be applied to digital transformation, including 1] ensuring the business remains competitive, 2] bringing efficiency in business processes, In this study, organizational culture is considered to be a moderating factor [reinforcing] the relationship between intellectual capital and organizational learning and its influence on organizational performance. Based on several theories, opinions, studies, and research findings on digital transformation, it is deemed necessary to have a digital transformation to moderate/strengthen intellectual capital ownership in improving organizational performance, and the need for digital transformation to improve or strengthen the effectiveness of organizational learning that has an impact on organizational performance improvement. Based on the description above, the research hypothesis can be made as follows:

H5The better intellectual capital will be able to improve organizational performance moderated by digital transformation

H6. The stronger organizational learning will be able to improve organizational performance moderated by organizational culture.

Based on the theoretical description and previous research studies, the conceptual framework of the research can be described as follows: 


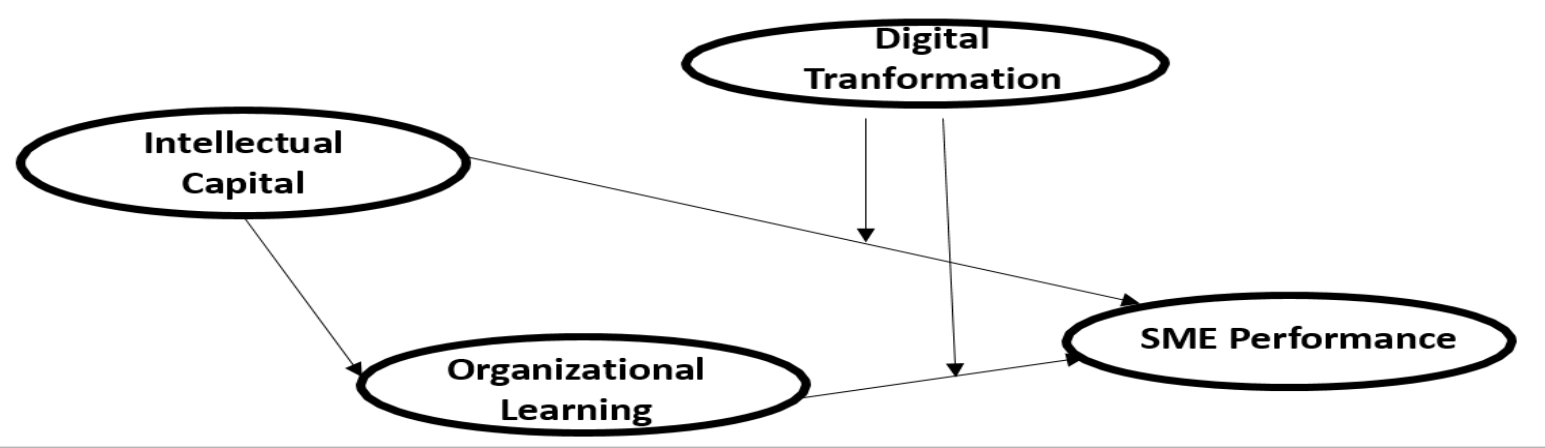

Fig. 1 Conceptual Framework

\section{METHOD}

This research is explanatory research that tries to explain the influence of one variable on other variables. The sample in this study was 174 MSME managers in Denpasar, Bali-Indonesia who were selected using random sampling. The data collection method is carried out by a combination of two, namely via email/online and distributed directly to respondents. Intellectual capital items were measured using an instrument developed by[23]. Organizational learning items were measured using an instrument developed by[24]. Digital transformation items using instruments from[19]. Business performance items are measured using instruments from[27] and [28]. Each variable was measured using a 5-point Likert scale [1 for Strongly Disagree -5 for Strongly Agree]. Data analysis was performed using Partial Least Square-Structural Equation Modelling [PLSSEM] with SmartPLS 3.2.9 software. PLS-SEM was chosen because this statistical analysis is a multivariate technique to predict a series of interdependence relationships between constructs simultaneously[29]. Test the validity and reliability of the instrument before the hypothesis is tested. The next step is to estimate the structural model to explain the influence between constructs.

\section{IV.RESULTS AND DISCUSSION}

\section{A. Data analysis}

In this study, inferential analysis was measured using Smart PLS software version 3.2.9, starting from measuring data quality (outer model), model structure (inner model) and hypothesis testing. The results obtained from several tests are shown in Table 1 which show that all indicators have met the requirements because the indicator has an outer loading above 0.5 and this already has convergent validity so that the model is feasible for further analysis.

\section{B. Data Quality}

After seeing the value of the loading factor and meeting the feasibility, then look at the results of testing the quality of the data. The results obtained in data quality testing are used outer model analysis to specify the relationship between latent variables and their indicators or it can be said that this defines how each indicator relates to its latent variables. The following is a summary of the results of the outer model testing which includes discriminant validity, composite reliability, and Cronbach alpha att Table II.

\section{TABLE I. FACTOR LOADING}

\begin{tabular}{lcc}
\hline \multicolumn{1}{c}{ Construct } & Original Sample [O] & P Values \\
\hline X1.1.2 <- Intellectual Capital & 0.837 & 0.000 \\
X1.1.3 <- Intellectual Capital & 0.820 & 0.000 \\
X1.2.1 <- Intellectual Capital & 0.767 & 0.000 \\
X1.2.2 <- Intellectual Capital & 0.653 & 0.000 \\
X1.3.2 <- Intellectual Capital & 0.757 & 0.000 \\
X2.1.1 <- Organizational Learning & 0.750 & 0.000 \\
X2.1.2 <- Organizational Learning & 0.712 & 0.000 \\
X2.2.1 <- Organizational Learning & 0.664 & 0.000 \\
X2.4.1 <- Organizational Learning & 0.745 & 0.000 \\
\hline
\end{tabular}




\begin{tabular}{lll}
\hline X2.4.2 <- Organizational Learning & & \\
X2.5.1<- Organizational Learning & 0.661 & 0.000 \\
X2.5.2 <- Organizational Learning & 0.724 & 0.000 \\
X3.1.1<- Digital Transformation & 0.793 & 0.000 \\
X3.1.2 <- Digital Transformation & 0.676 & 0.000 \\
X3.2.2 <- Digital Transformation & 0.747 & 0.000 \\
X3.3.1<- Digital Transformation & 0.659 & 0.000 \\
X3.3.2 <- Digital Transformation & 0.692 & 0.000 \\
Y.1<- SME Performance & 0.743 & 0.000 \\
Y.2<- SME Performance & 0.732 & 0.000 \\
Y.3 <- SME Performance & 0.741 & 0.000 \\
Y.4 <- SME Performance & 0.679 & 0.000 \\
Y.5 <- SME Performance & 0.720 & 0.000 \\
\hline
\end{tabular}

TABLE II

SUMMARY ROLE OF THUMBS OUTER MODEL

\begin{tabular}{|c|c|c|c|c|c|}
\hline Validity and Reliability & Parameter & Construct & Results & Criteria & Information \\
\hline \multirow{9}{*}{ Concergent Validity } & Loading Factor & & $0.653-0.857$ &.$>0.60$ & Accepted \\
\hline & \multirow{4}{*}{$\begin{array}{l}\text { Average Variance } \\
\text { Extracted [AVE] }\end{array}$} & $\begin{array}{c}\text { SME } \\
\text { Performance } \\
\end{array}$ & 0.523 &.$>0.50$ & Accepted \\
\hline & & $\begin{array}{l}\text { Intellectual } \\
\text { Capital }\end{array}$ & 0.592 &.$>0.50$ & Accepted \\
\hline & & $\begin{array}{l}\text { Organizational } \\
\text { Learning }\end{array}$ & 0.511 &.$>0.50$ & Accepted \\
\hline & & $\begin{array}{c}\text { Digital } \\
\text { Transformation }\end{array}$ & 0.511 &.$>0.50$ & Accepted \\
\hline & \multirow{4}{*}{ Communality } & $\begin{array}{c}\text { SME } \\
\text { Performance }\end{array}$ & 0.775 & $>0.50$ & Accepted \\
\hline & & $\begin{array}{l}\text { Intellectual } \\
\text { Capital }\end{array}$ & 0.838 & $>0.50$ & Accepted \\
\hline & & $\begin{array}{l}\text { Organizational } \\
\text { Learning }\end{array}$ & 0.842 & $>0.50$ & Accepted \\
\hline & & $\begin{array}{c}\text { Digital } \\
\text { Transformation }\end{array}$ & 0.761 & $>0.50$ & Accepted \\
\hline \multirow{3}{*}{ Discriminant Validity } & \multicolumn{2}{|l|}{ Cross Loading } & $0.653-0.857$ &.$>0.60$ & Accepted \\
\hline & \multirow{2}{*}{\multicolumn{2}{|c|}{$\begin{array}{l}\text { The square root of AVE Greater } \\
\text { correlation between Latent } \\
\text { constructs } \\
\text { Heterotrait-Monotrait Ratio } \\
\text { [HTMT] }\end{array}$}} & $0.715-0.770$ & $0.212-0.606$ & Accepted \\
\hline & & & $0.241-0.889$ & $<0.90$ & Accepted \\
\hline \multirow{6}{*}{ Reliability } & \multirow{4}{*}{ Cronbrach Alpha } & $\begin{array}{c}\text { SME } \\
\text { Performance } \\
\end{array}$ & 0.773 &.$>0.60$ & Accepted \\
\hline & & $\begin{array}{l}\text { Intellectual } \\
\text { Capital }\end{array}$ & 0.827 &.$>0.60$ & Accepted \\
\hline & & $\begin{array}{l}\text { Organizational } \\
\text { Learning }\end{array}$ & 0.840 &.$>0.60$ & Accepted \\
\hline & & $\begin{array}{c}\text { Digital } \\
\text { Transformation }\end{array}$ & 0.760 &.$>0.60$ & Accepted \\
\hline & \multirow[b]{2}{*}{ Composite } & $\begin{array}{c}\text { SME } \\
\text { Performance } \\
\end{array}$ & 0.846 &.$>0.60$ & Accepted \\
\hline & & Intellectual & 0.878 &.$>0.60$ & Accepted \\
\hline
\end{tabular}


DOI: $\underline{10.51386 / 25815946 / \mathrm{ijsms}-\mathrm{v} 4 \mathrm{i} 3 \mathrm{p} 122}$

Volume: 4 Issue: 3

May to June 2021

www.ijssmsjournal.org

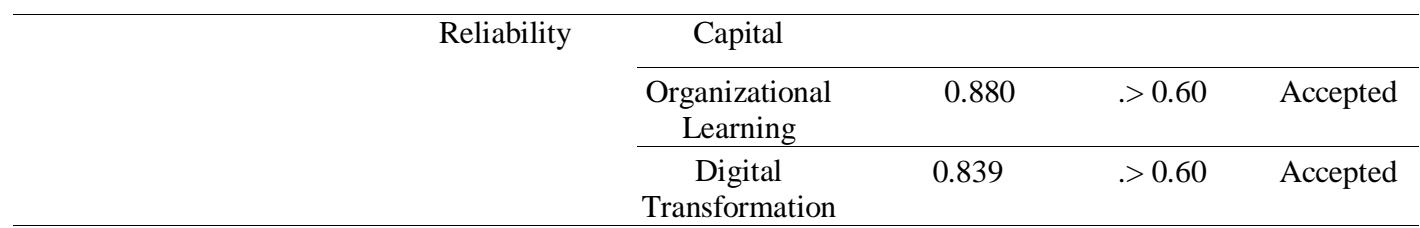

\section{Model Structure Test Results}

The results obtained in testing the structure of the model used inner model analysis. This describes the relationship between latent variables based on substantive theory. The following is a summary of the results of the structural model testing which includes $\mathrm{R}$ square, $\mathrm{f}$ square for effect size, and the relevance of Q2 predictions.

TABLE III

SUMMARY OF THE ROLE OF THUMBS STRUCTURAL MODEL

\begin{tabular}{|c|c|c|c|c|}
\hline Parameter & Construct & Results & Criteria & Information \\
\hline $\mathrm{R}$ square & & 0.534 & $\begin{array}{l}0.19 \text { Weak } \\
0.33 \text { Moderate } \\
0.67 \text { Strong }\end{array}$ & Moderate Model \\
\hline \multirow[t]{3}{*}{ Effect size } & Intellectual capital & 0.018 & $\begin{array}{l}\text { 0.02 Small } \\
0.15 \text { Medium } \\
0.33 \text { Big }\end{array}$ & Small Influence \\
\hline & $\begin{array}{l}\text { Organizational } \\
\text { Learning }\end{array}$ & 0.004 & $\begin{array}{l}0.02 \text { Small } \\
0.15 \text { Medium } \\
0.33 \text { Big }\end{array}$ & Small Influence \\
\hline & $\begin{array}{c}\text { Digital } \\
\text { Transformation }\end{array}$ & 0.290 & $\begin{array}{l}\text { 0.02 Small } \\
\text { 0.15 Medium } \\
0.33 \mathrm{Big}\end{array}$ & Medium influence \\
\hline \multicolumn{2}{|c|}{ Q2 predictive relevance } & 0.773 & $\begin{array}{l}0.02 \text { Weak } \\
0.15 \text { Moderate } \\
0.33 \text { Strong }\end{array}$ & $\begin{array}{l}\text { Strong } \\
\text { model }\end{array}$ \\
\hline
\end{tabular}

\section{Hypothesis Test RESUlts}

In testing the hypothesis, the correlation between constructs is measured by looking at the path coefficients and the level of significance which is then equated with the research hypothesis. The following table shows the results of hypothesis testing based on PLS bootstrapping.

\begin{tabular}{lcccc}
\hline The direction of Relationship Between Constructs & Original & T.Statistics & P.Values & Information \\
\hline Intellectual Capital -> MSME Performance & 0.144 & 1,443 & 0.150 & Not significant \\
Intellectual Capital -> Organizational Learning & 0.751 & 20,125 & 0.000 & Significant \\
Organizational Learning -> MSME Performance & 0.075 & 0.794 & 0.428 & Not significant \\
Transfer**Mod.In -> MSME Performance & 0.227 & 1,979 & 0.048 & Significant \\
Transform**Learning -> MSME Performance & 0.318 & 3,630 & 0.000 & Significant \\
Digital Transformation -> MSME Performance & 0.514 & 7,728 & 0.000 & significant \\
Intellectual Capital -> Organizational Learning -> MSME Performance & 0.056 & 0.793 & 0.428 Not significant
\end{tabular}


DOI: $\underline{10.51386 / 25815946 / i j s m s-v 4 i 3 p 122}$

Volume: 4 Issue: 3

May to June 2021

www.ijssmsjournal.org

\section{E. Discussion}

Based on table III above, the results of testing the influence of intellectual capital on the performance of medium-sized businesses can be proven by the estimated path coefficient value of 0.144 with a positive direction. The path coefficient which has a positive sign means that the relationship between the intellectual capital variable and the performance of medium-sized enterprises is unidirectional. The positive relationship is not significant, because it is evidenced by the P-Value value of 0.150 which is greater than the value of $=0.05$. The results of hypothesis testing [H1] prove that intellectual capital has a positive and insignificant effect on the performance of medium-sized enterprises. This means that the increase in intellectual capital is unidirectional and not significant to increase the performance of medium-sized businesses so that if there is an increase in intellectual capital performance it will lead to increased organizational performance but this increase is not necessarily able to improve the performance of medium-sized businesses. Thus, this study cannot prove the proposed hypothesis and at the same time cannot be accepted by the reality that occurs in the object of research. This research hypothesis is not supported, it can be caused because the measurement of intellectual capital variable in this study is more reflected by human capital indicators. While organizational performance is more dominantly reflected by indicators of productivity perspective. This means that the human capital indicator which is the main factor in the implementation of intellectual capital development, in reality, based on the characteristics of education and experience in managing the company, is mostly dominated by high school graduates to be the determining factor in achieving the level of productivity perspective on the performance of medium enterprises. This means that education is still low as a reflection of the competence of managers and this is a picture of low intellectual capital in medium-sized businesses in Denpasar City. This means that the human capital assets of medium enterprises in their perception are associated with high capacity, optimal utilization of intellectual intelligence, and having new ideas ultimately is not able to increase the productivity of MSME managers which is reflected in the low human capital of medium-sized enterprises in the city of Denpasar. His knowledge to complete the work, duties, and obligations carefully, precisely, and under the standards set by the organization. The results of this study are different from the findings of the research[23] which states that there is a positive and significant effect between intellectual capital on organizational performance; [3] that all indicators contained in intellectual capital contribute positively and significantly to improving organizational performance; [6] that intellectual capital [human capital] has a positive and real influence on the performance of SMEs.

Based on table III above, the results of testing the influence of intellectual capital on organizational learning can be proven by the estimated path coefficient value of 0.751 with a positive direction. The path coefficient which has a positive sign means that the relationship between intellectual capital variables and organizational learning is unidirectional. The positive relationship is significant because it is evidenced by the P-value of 0.000 which is smaller than the value of $=0.05$. The results of testing hypothesis $2[\mathrm{H} 2]$ prove that intellectual capital has a positive and significant effect on organizational learning. This means that the increase in intellectual capital performance is unidirectional and real to the increase in organizational learning so that if there is an increase in intellectual capital performance it causes an increase in organizational learning. Thus the research hypothesis proposed in this study can be accepted by the reality that occurs in the object of research. The results of the analysis found that intellectual capital directly has a positive and real influence on organizational learning. Thus the results of this study there is sufficient evidence to be able to prove that the better the implementation of intellectual capital development, the higher or more effective the learning process of medium-sized business organizations in Denpasar City. The findings of this study illustrate that the implementation of good intellectual capital development in medium-sized enterprises in Denpasar City can support variations in changes in increasing the effectiveness of the organizational learning process. The results of this study support the research findings From the results of the analysis found that intellectual capital directly has a positive and real influence on organizational learning. Thus the results of this study there is sufficient evidence to be able to prove that the better the implementation of intellectual capital development, the higher or more effective the learning process of medium-sized business organizations in Denpasar City. The findings of this study illustrate that the implementation of good intellectual capital development in medium-sized enterprises in Denpasar City can support variations in changes in increasing the effectiveness of the organizational learning process. The results of this study support the research findings From the results of the analysis found that intellectual capital directly has a positive and real influence on organizational learning. Thus the results of this study there is sufficient evidence to be able to prove that the better the implementation of intellectual capital development, the higher or more effective the learning process of medium-sized business organizations in Denpasar City. The findings of this study illustrate that the implementation of good intellectual capital development in medium-sized 
DOI: $\underline{10.51386 / 25815946 / i j s m s-v 4 i 3 p 122}$

Volume: 4 Issue: 3

May to June 2021

www.ijssmsjournal.org

enterprises in Denpasar City can support variations in changes in increasing the effectiveness of the organizational learning process. The results of this study support the research findings Thus the results of this study there is sufficient evidence to be able to prove that the better the implementation of intellectual capital development, the higher or more effective the learning process of medium-sized business organizations in Denpasar City. The findings of this study illustrate that the implementation of good intellectual capital development in medium-sized enterprises in Denpasar City can support variations in changes in increasing the effectiveness of the organizational learning process. The results of this study support the research findings Thus the results of this study there is sufficient evidence to be able to prove that the better the implementation of intellectual capital development, the higher or more effective the learning process of medium-sized business organizations in Denpasar City. The findings of this study illustrate that the implementation of good intellectual capital development in medium-sized enterprises in Denpasar City can support variations in changes in increasing the effectiveness of the organizational learning process. The results of this study support the research findings the findings of this study illustrate that the implementation of good intellectual capital development in medium-sized enterprises in Denpasar City can support variations in changes in increasing the effectiveness of the organizational learning process. The results of this study support the research findings the findings of this study illustrate that the implementation of good intellectual capital development in medium-sized enterprises in Denpasar City can support variations in changes in increasing the effectiveness of the organizational learning process. The results of this study support the research findings[12] and [15] which states that there is a positive and significant relationship between all elements of intellectual capital on organizational learning.

Based on table III above, the results of testing the effect of organizational learning on the performance of medium-sized enterprises can be proven by the estimated path coefficient value of 0.075 in a positive direction. The path coefficient which has a positive sign means that the relationship between organizational learning variables and the performance of medium-sized enterprises is unidirectional. The positive relationship is not significant, because it is evidenced by the P-value of 0.428 which is greater than the value of $=0.05$. The results of hypothesis testing [H3] prove that organizational learning has a positive and insignificant effect on the performance of medium-sized enterprises. This means that an increase in the performance of medium-sized enterprises is unidirectional and not significant to the increase in organizational learning so that if there is an increase in organizational learning, it is not able to increase the performance of medium-sized enterprises. Thus, this study cannot prove the proposed hypothesis and at the same time cannot be accepted by the reality that occurs in the object of research. Based on the demographic results, most of the respondents are still educated below high school which means that they only receive basic education, so that the process for organizational learning becomes hampered, this is also exacerbated by the lack of facilities or infrastructure to support organizational learning, such as the cost of training and education for employees in the business environment are found to be lacking or almost non-existent, so it can be said that business managers in developing organizational learning in medium-sized businesses in Denpasar City are still not or less adaptive to the external environment, does not continuously improve the capability to change, has not developed the ability to learn individually and collectively and has not used learning outcomes to achieve better results. The lack of contribution from mediumsized business managers to these factors can affect their performance. The results of this study are different from the findings of previous studies from[13] and [14] which show a positive and significant influence on organizational learning on organizational performance.

Based on table III above, the results of testing the direct influence of intellectual capital on the performance of medium-sized businesses can be proven by the estimated path coefficient value of 0.144 with a positive direction. The path coefficient which has a positive sign means that the relationship between organizational learning variables and organizational performance is unidirectional. The positive relationship is not significant, because it is evidenced by the $\mathrm{P}$-value of 0.428 which is greater than the value of $=0.05$ [H1], besides that in the analysis of the direct relationship of organizational learning to the performance of medium-sized enterprises, there is also an insignificant relationship [H3]. Thus, based on the criteria set by Ghozali [2021] that if the direct relationship of the mediating variable to the performance of medium-sized enterprises is not significant, it can be said that it is not a mediating variable. The results of testing the hypothesis [H4] found that there was insufficient evidence to accept [H4] that intellectual capital had a significant effect on the performance of medium-sized enterprises mediated by organizational learning. This means that the increase in the performance of medium-sized enterprises cannot be done through an increase in intellectual capital directly and also through an increase in intellectual capital followed by an increase in organizational learning. Thus it can be concluded that organizational learning in the relationship of intellectual capital to the performance of medium-sized enterprises is not a mediating variable. The results of this study are different from the findings of This means 
DOI: $\underline{10.51386 / 25815946 / \mathrm{ijsms}-\mathrm{v} 4 \mathrm{i} 3 \mathrm{p} 122}$

Volume: 4 Issue: 3

May to June 2021

www.ijssmsjournal.org

that the increase in the performance of medium-sized enterprises cannot be done through an increase in intellectual capital directly and also through an increase in intellectual capital followed by an increase in organizational learning. Thus it can be concluded that organizational learning in the relationship of intellectual capital to the performance of medium-sized enterprises is not a mediating variable. The results of this study are different from the findings of This means that the increase in the performance of medium-sized enterprises cannot be done through an increase in intellectual capital directly and also through an increase in intellectual capital followed by an increase in organizational learning. Thus it can be concluded that organizational learning in the relationship of intellectual capital to the performance of medium-sized enterprises is not a mediating variable. The results of this study are different from the findings of [12] and [15] which confirmed that intellectual capital has a positive and significant effect on the efficiency of new product development performance through mediating organizational learning capacity.

Based on table III above the results of the path analysis in the estimated path coefficient value is 0.227 with a positive direction. The path coefficient that has a positive sign means that the relationship between the interaction variables of digital transformation and intellectual capital on the performance of medium-sized enterprises is unidirectional. The positive relationship is significant, because it is evidenced by the P-value of 0.048 which is smaller than the value of $=0.05$, so it can be concluded that the digital transformation variable is a moderating variable between the influence of intellectual capital on the performance of medium enterprises. Thus the hypothesis H5 which states the better intellectual capital will be able to improve organizational performance moderated by digital transformation can be proven. This means that the relationship between intellectual capital and the performance of medium-sized enterprises depends on the implementation of digital transformation. The positive interaction coefficient means that the interaction between intellectual capital and digital transformation has a positive effect on the performance of medium-sized businesses. The higher the score for implementing digital transformation, the higher the role of digital transformation, so that it will have an impact on strengthening the influence of intellectual capital on the performance of medium-sized businesses. Based on the facts on the ground, mid-sized business managers have started to implement online marketing by utilizing social media.

Based on table III above, the results of the path analysis in the estimated path coefficient value is 0.318 with a positive direction. The path coefficient that has a positive sign means that the relationship between the interaction variables of digital transformation and intellectual capital on the performance of medium-sized enterprises is unidirectional. The positive relationship is significant, because it is evidenced by the P-value of 0.000 which is smaller than the value of $=0.05$, so it can be concluded that the digital transformation variable is a moderating variable between the influence of organizational learning on the performance of medium enterprises. Thus the hypothesis H5 which states the better intellectual capital will be able to improve organizational performance moderated by digital transformation can be proven. This means that the relationship between organizational learning and the performance of medium-sized enterprises depends on the implementation of digital transformation. The positive interaction coefficient means that the interaction between organizational learning and digital transformation has a positive effect on the performance of medium-sized enterprises. The higher the score for implementing digital transformation, the higher the role of digital transformation, so that it has the effect of strengthening the influence of organizational learning on the performance of medium-sized businesses. Based on the facts on the ground, mid-sized business managers have started to implement online marketing by utilizing social media

\section{Conclusions}

Based on the results of research on the influence of intellectual capital on the performance of mediumsized enterprises through organizational learning which is moderated by digital transformation in medium-sized enterprises in the city of Denpasar, several conclusions can be drawn as follows: First, high intellectual capital can increase the effectiveness of organizational learning. The implementation of the better influence of human capital, structural capital, and relational capital can directly increase the learning effectiveness of medium-sized business organizations. High intellectual capital has not been able to improve organizational performance. The implementation of high human capital, structural capital, and relational capital has not been able to improve the performance of medium-sized businesses. Second, effective organizational learning has not been able to improve organizational performance. The implementation of personal skills, mental models, sharing a shared vision, teamwork, and effective systems thinking have not been able to improve the performance of mediumsized businesses. Third, organizational learning is not able to mediate intellectual capital on the performance of 


\section{DOI: $\underline{10.51386 / 25815946 / \mathrm{ijsms}-\mathrm{v} 4 \mathrm{i} 3 \mathrm{p} 122}$}

medium-sized enterprises. The implementation of human capital, structural capital, and relational capital has not been able to improve the performance of medium-sized businesses through organizational learning. Fourth, the application of good digital transformation can strengthen the relationship of intellectual capital to improving organizational performance. Fifth, the application of good digital transformation can strengthen the relationship of organizational learning to improving the performance of medium-sized businesses. Third, organizational learning is not able to mediate intellectual capital on the performance of medium-sized enterprises. The implementation of human capital, structural capital, and relational capital has not been able to improve the performance of medium-sized businesses through organizational learning. Fourth, the application of good digital transformation can strengthen the relationship of intellectual capital to improving organizational performance. Fifth, the application of good digital transformation can strengthen the relationship of organizational learning to improving the performance of medium-sized businesses. Third, organizational learning is not able to mediate intellectual capital on the performance of medium-sized enterprises. The implementation of human capital, structural capital, and relational capital has not been able to improve the performance of medium-sized businesses through organizational learning. Fourth, the application of good digital transformation can strengthen the relationship of intellectual capital to improving organizational performance. Fifth, the application of good digital transformation can strengthen the relationship of organizational learning to improving the performance of medium-sized businesses.

\section{ACKNOWLEDGMENT}

The research team would like to thank the Chancellor of the University of Warmadewa Denpasar, BaliIndonesia for the research funding through the 2020/2021 Basic Research Institute Grant for the Warmadewa University Research Institute.

\section{REFERENCES}

[1] N. M. W. A. Pramuki and N. P. A. Kusumawati, "The Influence of Product Innovation , Digital Marketing and Competitive Advantage in Improving the Marketing Performance of Small and Medium Industries in Bali," in Advances in Economics, Business and Management Research, volume 175 "Proceedings of the 2nd International Conference on Business and Management of Technology (ICONBMT 2020),”2021, vol. 175, pp. 248-254.

[2] A. E. Nugroho, "Survei Kinerja UMKM di Masa Pandemi COVID19," Biro Kerja Sama, Hukum, dan Humas LIPI, 2020. http://lipi.go.id/berita/survei-kinerja-umkm-di-masa-pandemi-covid19/22071.

[3] M. Khalique, N. Bontis, J. A. N. Bin Shaari, M. R. Yaacob, and R. Ngah, "Intellectual capital and organisational performance in Malaysian knowledge-intensive SMEs," in International Journal of Learning and Intellectual Capital, 2018, vol. 15, no. 1, doi: 10.1504/IJLIC.2018.088345

[4] I. W. E. Arsawan, "Intellectual capital and innovation culture: evidence from SMEs performance in Indonesia," Econ. Ecol. Socium, vol. 3, no. 4, 2019, doi: 10.31520/2616-7107/2019.3.4-2.

[5] P. D. Astuti, A. Chariri, and A. Rohman, "Association between intellectual capital and competitive advantage: A case study on the hotel industry in bali province, Indonesia,” Humanit. Soc. Sci. Rev., vol. 7, no. 4, pp. 440-449, 2019, doi: 10.18510/hssr.2019.7460.

[6] M. Dabić, J. Lažnjak, D. Smallbone, and J. Švarc, "Intellectual capital, organisational climate, innovation culture, and SME performance: Evidence from Croatia,” J. Small Bus. Enterp. Dev., vol. 26, no. 4, 2019, doi: 10.1108/JSBED-04-2018-0117.

[7] S. Muda and M. Rahman, "Sectoral Effects Of Intellectual Capital On Malaysian Sme Business Performance," Asia-Pacific Manag. Account. J., vol. 14, no. 3, 2019.

[8] Istianingsih and R. Suraji, “The Impact of Competitive Strategy and Intellectual Capital on SMEs Performance,” J. Manaj., vol. 24, no. 3, 2020, doi: 10.24912/jm.v24i3.677.

[9] D. B. Tran and D. H. Vo, "Should bankers be concerned with Intellectual capital? A study of the Thai banking sector," J. Intellect. Cap., vol. 19, no. 5, pp. 897-914, 2018, doi: 10.1108/JIC-12-2017-0185.

[10] M. Joshi, D. Cahill, J. Sidhu, and M. Kansal, "Intellectual capital and financial performance: An evaluation of the Australian financial sector,” J. Intellect. Cap., 2013, doi: 10.1108/14691931311323887.

[11] I. W. K. Ting and H. H. Lean, "Intellectual capital performance of financial institutions in Malaysia," J. Intellect. Cap., vol. 10, no. 4, pp. 588-599, 2009, doi: 10.1108/14691930910996661.

[12] M. H. K. Nezam, A. Ataffar, A. N. Isfahani, and A. Shahin, "Human capital and new product development performance efficiencythe mediating role of organisational learning capability," Int. J. Innov. Learn., vol. 20, no. 1, 2016, doi: 10.1504/IJIL.2016.076670.

[13] T. Agustina, W. Gerhana, and , S., "The Effect of Locus of Control, Learning, and Adversity Quotient towards Micro Business Success (Study on Entrepreneurship under Foster Group of the Banjarmasin Regional Government)," J. Wetl. Environ. Manag., vol. 8, 


\section{DOI: $\underline{10.51386 / 25815946 / \mathrm{ijsms}-\mathrm{v} 4 \mathrm{i} 3 \mathrm{p} 122}$}

no. 1, 2020, doi: 10.20527/jwem.v8i1.215.

[14] F. Untari, “Analisis Peran Penting Gaya Kepemimpinan, Pembelajaran Organisasi, Remunerasi, dan Lingkungan Kerja terhadap Kinerja Pegawai pada Pengadilan Negeri ...," JEBDEKER J. Ekon. Manaj. ..., 2020.

[15] S. M. Allameh, S. Abbasi, and S. A. R. Shokrani, "The mediating role of organizational learning capability between intellectual capital and job satisfaction," Eur. J. Soc. Sci., vol. 17, no. 1, 2010.

[16] A. K. Patwary and F. Fauzan, "The Impacts of Human, Structural and Relational Capital on Product Development Performance in Manufacturing Organizations in Indonesia: Mediating Role of Organizational Learning Capabilities and R\&D Resources," $i R A S D J$. Manag., vol. 2, no. 2, 2020, doi: 10.52131/jom.2020.0202.0017.

[17] J. Fisher, "Contingency-based research on management control systems: Categorization by level of complexity," J. Account. Lit., vol. $14,1995$.

[18] I. K. Widjajanti and S. E. Mm, "Transformasi Organisasional Privatisasi BUMN di Indonesia," J. Ekon. Bisnis, vol. 10, no. 2, pp. $322-333,2009$.

[19] A. Sylvana and M. Awaluddin, “ Entrepreneurship at Global Crossroad : Challenges and Solutions ," in Seminar Nasional IX Fakultas Ekonomi Universitas Terbuka, 2017, pp. 1-17.

[20] W. Pertiwi and F. Nurhikma, "Pengaruh Perubahan Sistem Digitalisasi Terhadap Kinerja Karyawan," in Seminar Nasional Multidisiplin 2018, 2018, pp. 1-5.

[21] J. Barney, "Firm Resources and Sustained Competitive Advantage," J. Manage., 1991, doi: 10.1177/014920639101700108.

[22] H. Pusparini, Murabah, and Y. Mariadi, "Faktor-Faktor Kontijensi Yang Memengaruhi Pengimplementasian Praktik Akuntansi Maanajemen Pada Usaha Kecil Menengah (Umkm) Di Kota Mataram,” J. Apl. Akunt., vol. 5, no. 1, pp. 72-89, 2020, doi: 10.29303/jaa.v5i1.91.

[23] N. Bontis, K. William Chua Chong, and S. Richardson, "Intellectual capital and business performance in Malaysian industries," J. Intellect. Cap., vol. 1, no. 1, pp. 85-100, 2000, doi: 10.1108/14691930010324188.

[24] P. M. Senge, The Fifth Discipline : The Art and Practice of Learning Orientation. 2002.

[25] A. Hasan, P. Fithri, and I. Q. Annisa, "Pengaruh Kemampuan Pembelajaran Organisasi Terhadap Kinerja Industri Menengah Bidang Pangan di Kota Padang," Pros. SNTI dan SATELIT, pp. 215-222, 2017.

[26] A. Syah Putra et al., "International Journal of Science and Management Studies (IJSMS) Examine Relationship of Soft Skills, Hard Skills, Innovation and Performance: the Mediation Effect of Organizational Learning," Ijsmsjournal.Org, no. June, 2020.

[27] D. Wahyudiati, "Pengaruh Aspek Keuangan Dan Kompetensi Sumber Daya Manusia (Sdm) Terhadap Kinerja Usaha Mikro Kecil Dan Menengah (Umkm) Di Desa Kasongan,” Universitas Negeri Yogyakarta, 2017.

[28] M. Munizu, "Pengaruh Faktor-Faktor Eksternal dan Internal Terhadap Kinerja Usaha Mikro dan Kecil ( UMK ) di Sulawesi Selatan," 1990.

[29] J. Hair, W. C. Black, B. J. Babin, and R. E. Anderson, Multivariate Data Analysis: Pearson New International Edition. 2013. 